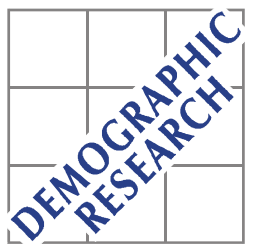

Demographic Research a free, expedited, online journal

of peer-reviewed research and commentary in the population sciences published by the Max Planck Institute for Demographic Research

Konrad-Zuse Str. 1, D-18057 Rostock · GERMANY

www.demographic-research.org

DEMOGRAPHIC RESEARCH

VOLUME 18, ARTICLE 1, PAGES 1-26

PUBLISHED 29 FEBRUARY 2008

http://www.demographic-research.org/Volumes/Vol18/1/

DOI: 10.4054/DemRes.2008.18.1

Research Article

Gender equity and fertility intentions in Italy and the Netherlands

Melinda Mills

Letizia Mencarini

Maria Letizia Tanturri

Katia Begall

(C) 2008 Mills et al.

This open-access work is published under the terms of the Creative Commons Attribution NonCommercial License 2.0 Germany, which permits use, reproduction \& distribution in any medium for non-commercial purposes, provided the original author(s) and source are given credit.

See http:// creativecommons.org/licenses/by-nc/2.0/de/ 


\section{Table of Contents}

1 Introduction 2

2 Previous research and theoretical framework 3

2.1 Classic approaches to explain low fertility 3

$2.2 \quad$ A gendered approach to explain low fertility 4

$\begin{array}{lll}2.3 & \text { Gender systems and low fertility } & 7\end{array}$

3 Data and methods $\quad 11$

3.1 Data 11

3.2 Variables used in the analysis and statistical methods 12

$\begin{array}{lll}4 & \text { Results } & 16\end{array}$

$\begin{array}{lll}5 & \text { Discussion } & 18\end{array}$

$\begin{array}{lll}6 & \text { Acknowledgements } & 20\end{array}$

$\begin{array}{ll}\text { References } & 21\end{array}$ 


\title{
Gender equity and fertility intentions in Italy and the Netherlands
}

\author{
Melinda Mills ${ }^{1}$ \\ Letizia Mencarini $^{2}$ \\ Maria Letizia Tanturri ${ }^{3}$ \\ Katia Begall ${ }^{4}$
}

\begin{abstract}
Fertility levels have fallen drastically in most industrialized countries. Diverse theoretical and empirical frameworks have had difficulty explaining these unprecedented low levels of fertility. More recently, however, attention has turned from classic explanations, such as women's increased labour market participation, to gender equity as the essential link to understand this phenomenon. Increases in women's labour market participation did not prompt a rise in men's domestic duties, often referred to as women's 'dual burden' or 'second shift'. Beyond the household, institutions and policies within countries facilitate or constrain the combination of women's employment with fertility. This paper provides an empirical test of gender equity theory by examining whether the unequal division of household labour leads to lower fertility intentions of women within different institutional contexts. Italy constitutes a case of low gender equity, low female labour market participation and the lowest-low fertility. The Netherlands has moderate to high gender equity, high part-time female labour market participation and comparatively higher fertility. Using data from the 2003 Italian Multipurpose Survey - Family and Social Actors and the Dutch sample from the 2004/5 European Social Survey, a series of logistic regression models test this theory. A central finding is that an unequal division of household labour only significantly impacts women's fertility intentions when they already bear a heavy load (more work hours, children), a finding that is particularly salient for working women in Italy.
\end{abstract}

\footnotetext{
${ }^{1}$ ICS/Department of Sociology, University of Groningen, Netherlands.

E-mail: m.c.mills@ rug.nl.

${ }^{2}$ Department of Statistics and Applied Mathematics, University of Turin, Italy.

E-mail: letizia.mencarini@unito.it.

${ }^{3}$ Department of Applied Statistics and Economics "L.Lenti", University of Pavia, Italy.

E-mail: tanturri@unipv.it.

${ }^{4}$ Department of Sociology, University of Groningen, Netherlands. E-mail: k.h.begall@ student.rug.nl.
} 


\section{Introduction}

Fertility levels have fallen well below replacement level in many industrialized countries, prompting some to argue that we are now experiencing a fertility crisis (Caldwell \& Schindlmayr, 2003). International organizations such as the United Nations (2000) have suggested that if these levels persist, countries would have to seek other options, such as massive migration to counter population decline. This decline in fertility has become an increasing concern, particularly in southern European countries where fertility levels have fallen well below the replacement rate for a longer period (Chenais, 1996). These unprecedented levels of low fertility have serious long-term consequences, including aging populations, a decline in the active working population and smaller overall populations (Teitelbaum \& Winter, 1985).

A large body of research has focussed on potential reasons and underlying theories to explain low fertility, ranging from economic motives and opportunity costs of having children, to economic uncertainty and shifts in ideology and investments in children. More recently, however, gender equity has been posited as an essential link in understanding the low fertility phenomenon (McDonald 2000a; Cooke 2003). The changing position of women, including women's increased participation in education and the labour force and the availability of reliable forms of contraception, has been seen as vital to interpret decreases in fertility (Rindfuss et al., 1996). Women's increased participation in education and the labour market, however, provides only a partial explanation.

First, it is not only women's behaviour, but also the behaviour of their partners that affects fertility intentions. Although women across many Western countries now achieve high levels of education and participate in the labour market, women's role and the division of household labour within the family has remained relatively constant. This is what Hochschild (1989) referred to as the 'stalled revolution'. A second key factor is the 'gender system' in each country, which entails the different rights and obligations provided to men and women. Gender systems are increasingly viewed as the missing link in understanding the persistence of low fertility (Mason and Oppenheim, 1997). McDonald $(2000 \mathrm{~b}$; 2006) proposes that this disparity is attributed to varying levels of gender equity in different social institutions. Countries such as the Netherlands, Denmark, Finland, and Sweden for instance, maintain both relatively high levels of total fertility of around 1.8, coupled with high levels of gender equity. Whereas countries such as Italy, Spain and Greece have very low total fertility rates of around 1.3, coupled with high gender inequality (McDonald, 2006: 499). The dominant male-breadwinner family model, accompanied by tax and state benefits for families that favour one-earner couples, and a lack of available or affordable institutionalized childcare make it difficult for women to combine work and parenthood (Kreyenfeld \& 
Hank, 2000). When they do attempt this, they take on not only the role of paid worker, but also remain the largest contributor to housework and caring tasks.

This paper provides an empirical test of gender equity theory by exploring whether the unequal division of household labour has an impact on the fertility intentions of women in the diverse institutional settings of Italy and the Netherlands. Italy constitutes a case of low gender equity, low female labour market participation and the lowest-low fertility. The Netherlands has moderate to high gender equity, high part-time female labour market participation and comparatively higher fertility. This study therefore attempts to identify whether a link exists between asymmetrical gender division of household labour and low fertility. We assume that women make fertility decisions not only based on current participation in paid and unpaid labour, but with future expectations of how their lives would develop with (additional) children. Our central hypothesis is that for women who engage in the majority of domestic labour, childbearing is seen to exacerbate an already heavy and unbalanced division of household labour. This in turn encourages women to limit their fertility intentions. We anticipate that this effect will be particularly strong for women already balancing the multiple roles of mother and paid worker, and for those in institutional contexts with weak support for combining work and parenthood.

This paper first sketches previous theories and research on this topic in order to draw hypotheses and come to a deeper understanding of the process that links the unequal division of household labour with low fertility. Within this section, we also highlight the relevant institutional and behavioural differences between Italy and the Netherlands. This is followed by a description of the data and methods used in this study and presentation of the main results. We conclude with a reflection on our findings and pay particular attention to future policy directives in this area.

\section{Previous research and theoretical framework}

\subsection{Classic approaches to explain low fertility}

A variety of theories and approaches have been developed to explain low fertility (for a review see for example, van de Kaa, 1996; Caldwell \& Schindlmayr, 2003; Morgan \& Taylor, 2006). The focus has ranged from the study of classic determinants that undermine incentives for childbearing such as economic change (Davis, 1937) or the direct or indirect opportunity costs of having children (Becker, 1981). Others have argued that fertility postponement, which may ultimately result in foregone fertility, is a rational response to the economic insecurity and increasing opportunity costs of childbearing for women (Kohler et al. 2002; Mills, Blossfeld \& Klijzing, 2005). 
Additional factors also include shifts in ideology and the investments in children, often referred to in relation to the second demographic transition (Lesthaeghe \& van de Kaa, 1986; van de Kaa, 1987; Lesthaeghe, 1995).

Economic theories have explained low fertility to be triggered by women's increased economic independence (Becker, 1981), mainly through improved education and higher labour-force participation. This in turn reduces the gains from marriage based on the interdependence of the traditional gender division of labour in the family, and increases the relative cost of childbearing (via women's foregone earnings while they care for the children at home or reduce their work hours). Although gender is a major explanatory factor in these classic theories, feminist scholars have argued that overlapping gender-roles may, in fact, strengthen family relationships, whereas rolespecialization makes the family vulnerable whenever the abilities of one or both partners to provide their particular contribution (earnings or care) diminish (Oppenheimer, 1994). Moreover, high female employment rates can be combined with relatively high fertility when policies and home-sphere gender relations facilitate the combination of paid work and parenthood (Bernhardt, 1993; Brewster \& Rindfuss, 2000).

An added criticism is that women's labour market participation and fertility intentions cannot be understood by examining only current behaviour. Rather, we need to also anticipate decision-making based on future expected outcomes. It is not merely participation in paid labour that sways women's fertility decisions, but the amount of work that they engage in at home in their 'second shift' (Hochschild, 1989). In other words, women who are already participating in the labour market, and doing a large share of domestic work, may be deterred from having children due to the expectation that it will damage their future labour market or individual development prospects. In many countries, having children can seriously compromise women's job opportunities. This situation can in itself drive some women to reduce the number of children they have or even forego parenthood altogether (Matthews, 1999; Scisci \& Vinci, 2002; Mencarini \& Tanturri, 2006; Tanturri \& Mencarini, 2008).

\subsection{A gendered approach to explain low fertility}

In recent years, a growing body of theoretical and empirical research has emerged that examines the impact of gender systems and gender inequality on fertility. Studies stem from the pioneering work of Folbre (1983), Oppenheimer (1994), and Mason and Oppenheim (1997), to the more recent theoretical work of McDonald (e.g., 2000a; 2000b; 2006). The numbers of empirical studies analyzing this subject with micro data are relatively rare (see Olah 2003, on the transition to second child in Hungary and 
Sweden; Miller Torr \& Short 2004 on US; Cooke, 2003 on Italy and Spain; Mencarini \& Tanturri 2004, on Italian urban contexts). Existing results provide overwhelming evidence that the time-squeeze for working mothers is indeed real. In contexts where childcare services or other support such as part-time or flexible hours for working mothers are not available, the behaviour of fathers is fundamental. In fact, the participation of fathers in household duties appears to increase both the intentions and likelihood for the couple to have more children.

Fertility theory has therefore also embraced gender equity as a possible explanation of lowest-low fertility in Southern Mediterranean countries (Ongaro, 2002). McDonald (2000b) suggests that very low fertility may be the result of a hiatus that has developed in some developed countries between "high levels of gender equity in individual-oriented social institutions and sustained gender inequity in family-oriented social institutions". If in recent decades women have been given the same opportunities as men in education, and to some extent, in the labour market, this has not occurred within the family. The shift to a more gendered approach also entails moving from not only a study of the individual but also household and institutional determinants.

Over two decades ago, Folbre (1983: 267) argued that ignoring power relations within the household was a "fatal error of omission" in fertility theory. One such proxy of power is the level of education, which in turn influences the bargaining power of women in the household. We anticipate that women who have higher levels of education will be more empowered in their decision-making both in relation to household labour and fertility. This is not only attributed to higher levels of human capital and the ability to assert their power, but also the fact that education allows them to question traditional roles (McDonald, 2006). Furthermore, various studies have demonstrated that couples with higher education have a more even division of household labour compared to those with lower levels of education (Gershuny \& Robinson, 1988; Mencarini \& Tanturri, 2004). Others have argued that the highly educated (often working) women have higher opportunity costs or 'more to lose' if they have children (e.g., Becker, 1981). However, we foresee an opposite effect with the following hypothesis. Due to a more even division of household labour, higher economic assets and the ability to break traditional roles, highly educated women will have higher fertility intentions compared to those with lower education. This effect is not only likely attributed to their ability break traditions and bargain in the household, but also their economic ability to outsource domestic tasks. Conversely, women who have very low education may indeed initially have higher fertility intentions, but the reality of economic constraints, a more uneven division of household labour and an inability to break from traditional roles weakens these goals. This resounds with other recent European studies such as Kravdal (2007), who demonstrated that higher education among women stimulated higher fertility (to second and third births). 
Although there is a higher percentage of childlessness among the highly educated and their births are often postponed, there is growing evidence that these individuals not only have high fertility intentions, but also possess the resources to turn intentions into behaviour.

Although the level of education provides a useful measure, the actual division of housework within the household is a more direct measure of power and equity. This has also been the central focus of previous studies on this topic. Miller Torr and Short (2004) found that the relationship between gender equity - as indicated by division of housework - and fertility is U-shaped in the US. They found that in dual-earner couples, both 'modern couples' (where women do less than 54\% of housework) and 'traditional couples' (where women do more than $84 \%$ of housework) were more likely to have second birth. Using Eurobarometer data for 15 European countries, Alonso (2004) also found a significant positive correlation between fertility levels and the ideal distribution of childcare tasks and the actual distribution of housework tasks. In the same study, however, no correlation was found between fertility and the actual share of childcare tasks.

Tazi-Preve et al. (2004) shows a depressive effect of the unequal distribution of household labour on fertility intentions in Austria. This concurs with the work of Olah (2003), who found that in both and Sweden and Hungary, a more equal gender division in household tasks accelerates the transition to the second child, noting that specific policies in Sweden supported this transition. Using European Community Household Survey data for Italy and Spain, Cooke (2003) also concludes that a substantial involvement of fathers in care activities with the first child facilitates the transition to the second child among young couples. Finally, using data from a survey conducted in five urban areas (Udine, Padua, Florence, Pesaro and Messina), Mencarini and Tanturri (2004) found a higher likelihood of having a second child among working women if the father increased his involvement in housework after a first birth, and if the mother did not reduce her working hours after the first child. Based on these findings, we therefore hypothesize the following relationship between the household division of labour and fertility intentions. Women who engage in a large share of household labour (>75\%) will have lower fertility intentions than those who engage in a low share of household labour $(<75 \%)$.

Other research (e.g., Becker \& Moen, 1999) has demonstrated that it is not merely the large share of household labour, but conflicting roles in the realm of paid employment and parenthood that result in higher strains on women, which may in turn limit their fertility. For this reason, the majority of existing micro studies also concentrate on the transition to the second child. The experience of parenthood often implies a crystallization of gender roles, with an increase of women's time spent in housework and childcare, as well as a decrease in leisure time. This dual burden or 
second shift is what tends to cause the most strain on women. The reconciliation of roles within and outside the family is more difficult for a working mother than for a father, and often the strategies adopted are completely different. Men typically increase the time devoted to paid work and women decrease their working time or even exit the labour market (Anxo et al., 2007, Mencarini \& Tanturri, 2004, Lo Conte and Prati, 2003). For reasons such as these, previous studies (Cooke, 2003; Mencarini \& Tanturri, 2004) have shown that the gender symmetric role-set of parents increases their likelihood to have one more child in Italy. To capture this 'dual burden' effect and in an extension of the previous hypothesis we therefore expect that: Women who engage in a large share of household labour (>75\%) and: a) work a high number of hours in paid employment (>30 hours/week) and/or, b) already have one or more children - will have lower fertility intentions.

\subsection{Gender systems and low fertility}

Gender equity is not only relevant within the household, but also at the institutional and national level. Mason and Oppenheim (1997) defines these larger gender systems as socially constructed expectations for men and women that "prescribe a division of labour and responsibilities between women and men and grant different rights and obligations to them" (1997: 158). The level of gender development and institutions that support women and men to combine work and care differ greatly per country. Cultural norms surrounding working mothers, availability, affordability and use of childcare and the division of labour form a central part of these gender systems. More tangible institutions and related policies relevant for this topic include: tax systems and regulations, employment regulations and specifically in relation to flexible or part-time work, level and acceptability of working women and mothers, contraceptive availability and acceptance, childcare legislation, affordability and availability. We focus on several of these aspects that are particularly relevant when comparing the Dutch and Italian case.

At the national level, we see that industrialized countries with very low fertility are also generally the ones that can be characterized as having more unequal gender systems. Figure 1 plots the total fertility rates and the Gender-Related Development Index (GDI) for a selection of countries between 2000/1. The aim of the GDI is to measure the inequalities between men and women in the areas of life expectancy, knowledge and the standard of living. This figure not only demonstrates this relationship, but shows clear clustering according to institutional context, which follows classic institutional and welfare regime categorizations (Esping-Andersen, 1990), but also incorporates the Southern or more family-oriented and post-socialist welfare 
regimes (e.g., Mills \& Blossfeld, 2005). Figure 1 shows evident clustering of postsocialist countries, which have both low fertility and low levels of gender equity (which is also likely related to the GDI's focus on life expectancy and standard of living). This is followed by the southern, more family-oriented regimes, which include Greece, Portugal, Italy and Spain. The conservative or corporatist regimes such as Germany and Switzerland consist of another general group. The social-democratic regimes, including the Scandinavian countries, France and the Netherlands, make up the next group. This is in line with the work of Fuwa (2004), who demonstrated that macro-level gender inequality limited the effects of individual-level variables (e.g., education, resources) on the division of housework. Undertaking an analysis of 22 countries, Fuwa (2004) demonstrated that women in less egalitarian countries benefited less from their individual-level assets, concluding that reduction of inequality in the household should be tackled at a societal and not individual level.

Figure 1: Total Fertility Rate (TFR) and gender-related development index for selected countries

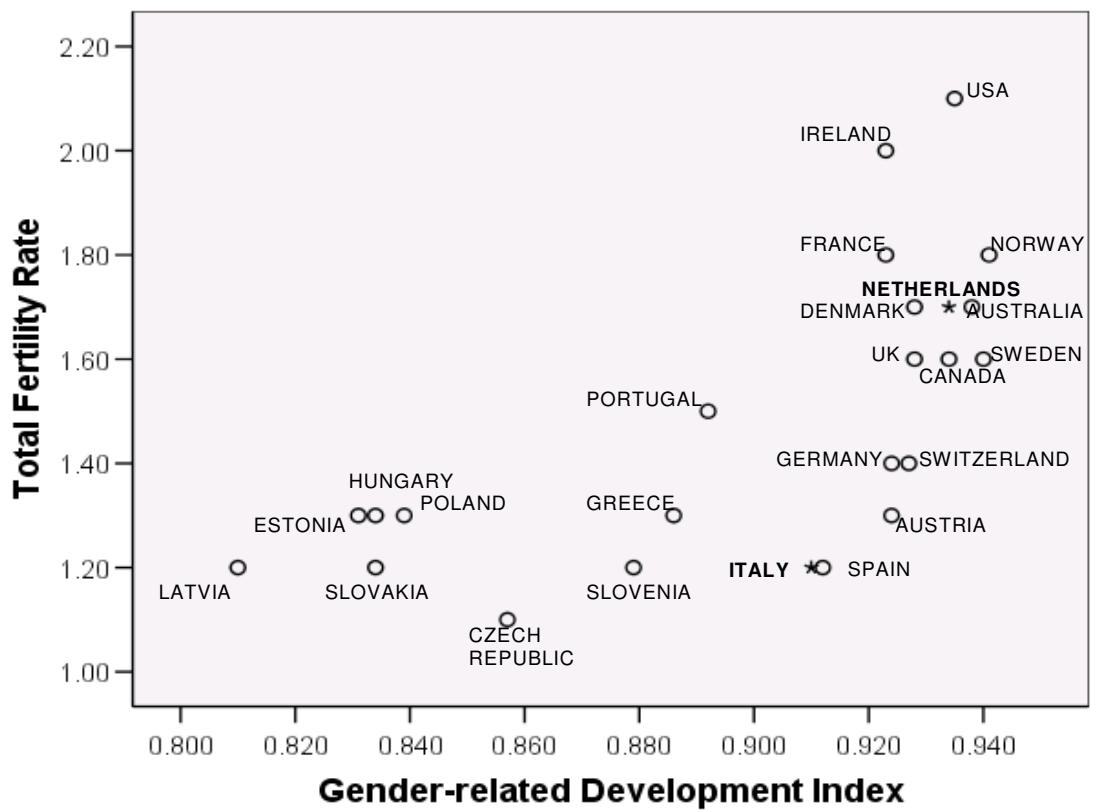

Source: TFR, United Nations http://www.un.org/esa/population/publications/worldfertility/Selected_Indicators.xls GDI, Human Development Report (2003), Table 22, Gender-related development Index

Note: Dates of TFR vary between 2000 and 2001, GDI is 2001 
Another relevant institutional consideration is the level of female labour market participation and more specifically, the level of mothers who are employed in the labour market. Figure 2 shows the employment rates in 2003 of women (in percentages) by the presence of children for the Netherlands and Italy in comparison with the OECD average (OECD, 2006). A striking difference is the levels of labour market participation between the two countries. In the Netherlands, almost 80 percent of women without children are employed, followed by around 75 percent of mothers with one child working, which falls just below 70 percent for those with two or more children. Dutch women's employment is concentrated in part-time jobs, interspersed with exits from the labor market during childbearing and rearing periods (van der Lippe \& van Dijk, 2002). Italy is in stark contrast to other OECD countries and the Netherlands, with just over 57 percent of women without children in the labour market, which drops to below 55 percent when they have their first child and more sharply to 45 percent in the presence of 2 or more children.

Figure 2: Employment rates of women (in \%) by presence of children, OECD average, the Netherlands and Italy, 2003

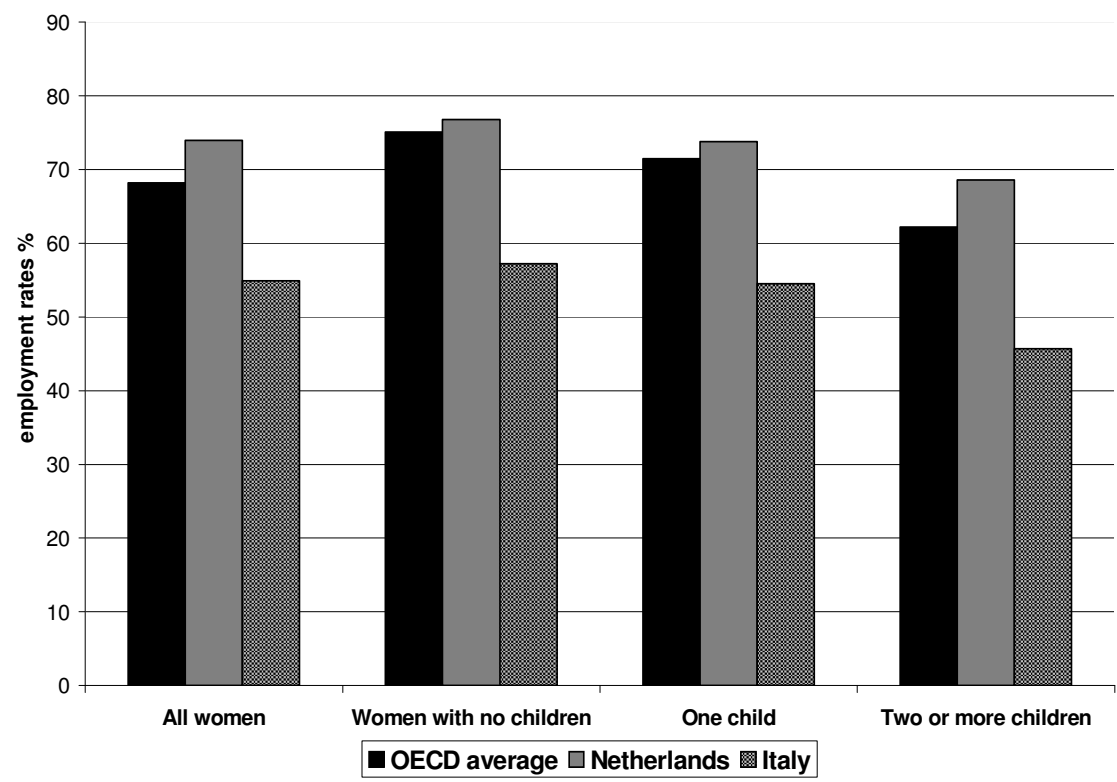

Source: Society at a Glance: OECD Social Indicators 2006 Edition, figure produced by authors. 
To understand these different contexts, we can turn to nation-specific contextual explanations. Dalla Zuanna (2001) provides a rich description of how the familyoriented Italian model penetrates all areas of institutional and social life, relating this to low fertility. Dalla Zuanna argues that endemic familialism generates a strong preference for having a low number of children as a strategy to assure more privileges and opportunity to each child. This strategy also presents large obstacles to leave the parental home, which can be linked indirectly to low fertility. Yet in Italy it is not only postponement of life events, he argues, but a failure to marry and have children, which in turn increases the number of childless women. Del Boca (2002 and Del Boca \& Vuri 2007) attribute the low labour market participation rates and low fertility of women in Italy to the Italian institutional structure and specifically the rigid labour market system and weakness of the publicly funded childcare system. These constraints operate to both discourage the labour market participation of women and greatly increase their costs of having children.

Bettio and Villa (1998) contend that the threat of high unemployment rates (particularly for women) in Italy make it virtually impossible for women to risk taking career breaks to have children, due to extreme difficulties to re-enter the labour market. Resistance by unions to part-time work in Italy coupled by regulations, which make it more expensive to hire two part-time workers than one full-time worker, reflects some of this rigidity (Del Boca 2002). Although childcare services in Italy are highly subsidized, the main problem is the scarcity of public childcare for children under three years old and the extreme rigidity in the number of hours that services for both preschool and school children are available. Others (Kreyenfeld \& Hank, 2000) have highlighted the disparity between affordability and actual availability of childcare as a central issue in other European countries as well. Childcare services are generally more compatible with part-time employment, which is relatively rare in Italy. Another clear difference between the two countries is the use of childcare facilities. In Italy, only a minority of children under the age of 3 are in public childcare $(6 \%$ according to the OECD Family Database), but between the ages of 3 and 6, most are in public care $(71 \%)$. Whereas, in other European countries, such as the Netherlands and Sweden, around $1 / 3$ of children under the age of 3 are in public childcare (CRRU, 2004).

The employment of women and particularly mothers is therefore not only a central factor in understanding the impact of gender systems on low fertility, but also a large difference between the two countries. In the Netherlands, active labour market policies were introduced to promote flexible working hours, particularly aimed at the part-time employment of women (Plantenga, 1996). This resulted in a flood of women into the labour market working part-time during the last decades. In addition to labour market developments, others have argued that the religious composition and persistent effects of religion on fertility and married women's labour market participation have resulted 
in these part-time work patterns in the Netherlands (De Graaf \& Vermeulen, 1997). Van Wel \& Knijn (2006) maintain that the part-time labour market participation of Dutch mothers is primarily caused by cultural factors and not economic or institutional constraints. They contend that a 'culture of care' dominates, as does the one-and-a-half earner model where the man works full-time and the woman part-time. This model is particularly dominant among those with lower education. For those with higher education, the tendency is for both partners to attempt to work part-time, although this is only achieved within a very limited group. Based on these institutional and cultural differences, we anticipate that women in Italy will face higher institutional and family constraints than in the Netherlands, which will in turn limit their fertility intentions. As outlined in the previous hypothesis, we expect that these constraints will be particularly poignant for Italian working women who engage in both substantial paid labour combined with a heavy load of household duties.

\section{Data and methods}

\subsection{Data}

Two different data sources were used for this analysis, using identical sample restrictions. Due to the fact that the research question concerns the share of household labour, respondents who are not co-residing with their partners are excluded from the analysis. Couples who are both cohabiting or married are included in the analyses. The age in both samples has also been restricted to between 20 and 40 years old. This is due to the fact that women older than 40 are unlikely to have further fertility intentions (which was the case in both samples).

The Dutch data are taken from the second wave of the European Social Survey (ESS), 2004/2005, a large-scale quantitative survey that was administered in 26 countries. Each wave of the ESS consists of a core questionnaire on attitudes and values and rotating modules. The second wave contains a module on family, work, and wellbeing which contains information on the combination of work and family life and fertility intentions which makes this questionnaire particularly suitable for this study. The Dutch sample consisted of a random sample of 1,881 respondents, which after sample restrictions was reduced to 213 respondents. For Italy, the 2003 Multipurpose Family and Social Actors survey "Family and Social Actors" was used, using a subsample of 3,458 couples (either married or cohabiting). The Survey provides detailed information on gender role-set and fertility intentions. Around $57 \%$ of the selected couples are dual-earners. We were unable to use the ESS for Italy due to the fact that it is a rotating panel, with the section containing the relevant questions including only half 
of the sample, resulting in too few cases. The ESS was used for the Dutch sample due to the fact that contemporary (and publicly available) Dutch data sources, such as the Netherlands Kinship Panel Study, do not have comparative information about the amount/share of household labour.

\subsection{Variables used in the analysis and statistical methods}

The dependent variable of fertility intentions was measured by a question that appeared in both surveys about the intentions to have a child within the next 3 years. The categories of definitely not and probably not were classified as no, with probably and definitely yes categorized as yes.

The highest level of education for both the respondent and their partner is represented by three comparative categories. Lower secondary represents those who have not completed primary school to those who have completed this level or the first stage of basic education. Upper secondary education refers to those who have completed lower secondary school or technical training. The highest level of postsecondary or tertiary education group includes those who completed lower secondary school theoretical training up to the highest level of tertiary education (i.e., $\mathrm{PhD}$ ).

Working hours were classified as the total number of hours per week according to the worker's contract (thus excluding overtime). In the ESS, household labour is defined as things done around the home, including cooking, washing, cleaning, care of clothes, shopping, maintenance of property, but not including childcare and leisure activities. Respondents were first asked how many hours in total on both a typical weekday and weekend do people in their household spend on housework. They were then asked about the share of this housework that they engaged in, ranging from none, to approximate estimations (e.g., quarter, to half, three quarters) up to all or nearly all of the time. With these variables we were able to create a proxy of household hours worked by the respondent and create a measure of the share of household work by the respondent. The measure in the Italian multipurpose survey includes both hours of housework (as defined above), but also family work. This results in an underestimation of household work and care in the Netherlands. When we compare the mean hours of housework per week by the respondent, we see that it is 17.62 in the Netherlands and 34.61 in Italy. The mean hours of housework per week by the partner are 4.27 and 6.57 respectively. This difference in the total number of housework hours per week, particularly for women, could be attributed to the lack of measuring family care in the Netherlands, but may also represent true differences between time spent in household labour between these countries. We reflect again on this aspect during the discussion of the results and in the conclusion. 
Finally, we also included age of the respondent, and number of children in the household in the model. To facilitate interpretation and comparison between different groups of respondents, all items except for age and hours of household labour have been recoded into categorical variables (see Table 1 for descriptive statistics of all items used).

Table 1: Descriptive statistics of variables used in the analysis, women 20-40 years old, the Netherlands and Italy

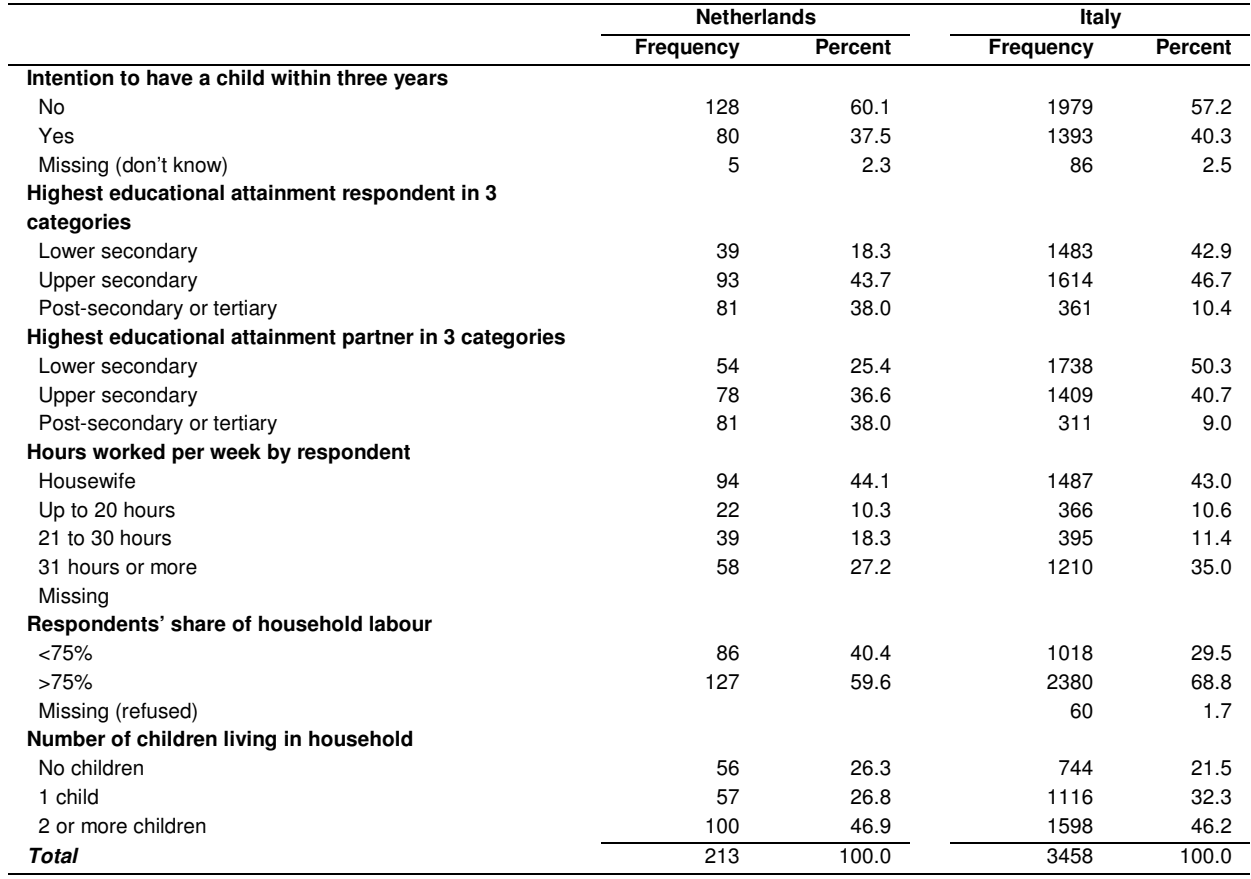

Source: Netherlands, European Social Survey (ESS), Wave 2, 2004/5; Italy, Italian Multipurpose Survey (IMS) - Family and Social Actors, 2003 
Mills et al:: Gender equity and fertility intensions in Italy and the Netherlands

A series of logistic regression models examine the fertility intentions of women in both countries. The first model examines the impact of key variables including: education of respondent and partner, age, weekly hours paid labour by respondent, number of children, hours of unpaid household labour and the share of the household work by the respondent. The second model then includes the two interaction effects of share of household work by: a) number of children and, b) hours of paid employment. Model 3 includes the full model (with interaction effects) for working women only. As Table 1 illustrates, 43 percent of women in the Italian sample report zero work hours, roughly the same as in the Netherlands $(44 \%)$.

Table 2: Results of logistic regression on intention to have another child by selected variables, the Netherlands and Italy

\begin{tabular}{|c|c|c|c|c|c|c|}
\hline \multirow[b]{3}{*}{ Variables in the Analysis } & \multicolumn{6}{|c|}{ Netherlands } \\
\hline & \multicolumn{2}{|c|}{ Model $1^{\mathrm{a}}$} & \multicolumn{2}{|c|}{ Model $2^{\mathrm{b}}$} & \multicolumn{2}{|c|}{ Model $3^{\mathrm{C}}$} \\
\hline & $\overline{\operatorname{Exp}(B)}$ & Sig. & $\operatorname{Exp}(B)$ & Sig. & $\operatorname{Exp}(B)$ & Sig. \\
\hline Education respondent (Reference $=$ lower secondary) & & .026 & & .047 & & .575 \\
\hline Education = upper secondary & 1.224 & .624 & 1.102 & .021 & .837 & .840 \\
\hline Education $=$ post-secondary or tertiary & 2.555 & .027 & 2.273 & .060 & 1.528 & .642 \\
\hline Education partner (Reference $=$ lower secondary) & & .142 & & .046 & & .015 \\
\hline Education partner $=$ upper secondary & 2.109 & .048 & 2.686 & .014 & 4.174 & .056 \\
\hline Education partner $=$ post-secondary or tertiary & 1.701 & .174 & 2.210 & .056 & 9.591 & .004 \\
\hline Age & .809 & .000 & .801 & .000 & .784 & .000 \\
\hline Hours worked per week (respondent) (Reference $=0$ hours, housework) & & .723 & & .878 & & .075 \\
\hline Hours worked 1 to 20 hours & 1.144 & .840 & .742 & .798 & & \\
\hline Hours worked $=21$ to 30 & .990 & .986 & .406 & .435 & 2.245 & .683 \\
\hline Hours worked $=>30$ & .572 & .352 & .841 & .834 & 36.932 & .047 \\
\hline Number of children (Reference $=$ no children) & & .000 & & .000 & & .045 \\
\hline 1 child & 1.525 & .214 & 2.339 & .015 & 86.712 & .016 \\
\hline 2 or more children & .161 & .000 & .223 & .000 & 2.518 & .517 \\
\hline Hours of household work by respondent & .966 & .074 & .969 & .113 & 1.318 & .030 \\
\hline $\begin{array}{l}\text { Share of household work by respondent }>75 \% \text { of household work } \\
\text { (Reference }=<75 \% \text { ) }\end{array}$ & 1.221 & .584 & 10.930 & .011 & 1.787 & .345 \\
\hline $\begin{array}{l}\text { Interaction of share of household work by number of children } \\
\text { (Reference }=<75 \% \text { of housework, no children) }\end{array}$ & & & & .093 & & .040 \\
\hline$>75 \%$ of household, 1 child & & & .194 & .042 & .720 & .012 \\
\hline$>75 \%$ of household, 2 or more children & & & .212 & .065 & .802 & .047 \\
\hline $\begin{array}{l}\text { Interaction of share of household work by hours worked } \\
\text { (Ref. }=<75 \% \text { of housework, } 0-20 \text { hours work) }\end{array}$ & & & & .033 & & .020 \\
\hline$>75 \%$ of household, 21 to 30 hours work & & & .700 & .741 & .921 & .488 \\
\hline$>75 \%$ of household, $>30$ hours work & & & .123 & .016 & .707 & .009 \\
\hline Constant & 2259.239 & .000 & 275.746 & .000 & 25.382 & .247 \\
\hline \multirow[t]{2}{*}{$-2 \mathrm{LL}$} & 183.368 & & 171.001 & & 105.198 & \\
\hline & & 213 & & 213 & & 116 \\
\hline
\end{tabular}




\section{Table 2: $\quad$ (Continued)}

\begin{tabular}{|c|c|c|c|c|c|c|}
\hline \multirow[b]{3}{*}{ Variables in the Analysis } & \multicolumn{6}{|c|}{ Italy } \\
\hline & \multicolumn{2}{|c|}{ Model $1^{\mathrm{a}}$} & \multicolumn{2}{|c|}{ Model $2^{b}$} & \multicolumn{2}{|c|}{${\text { Model } 3^{c}}^{c}$} \\
\hline & $\overline{\operatorname{Exp}(B)}$ & Sig. & $\operatorname{Exp}(B)$ & Sig. & $\operatorname{Exp}(\mathrm{B})$ & Sig. \\
\hline Education respondent (Reference $=$ lower secondary) & & .000 & & .000 & & .000 \\
\hline Education = upper secondary & 1.306 & .014 & 1.314 & .012 & 1.631 & .001 \\
\hline Education = post-secondary or tertiary & 2.082 & .000 & 2.082 & .000 & 2.599 & .000 \\
\hline Education partner (Reference = lower secondary) & & .079 & & .077 & & .045 \\
\hline Education partner = upper secondary & 1.237 & .045 & 1.239 & .045 & 1.406 & .016 \\
\hline Education partner = post-secondary or tertiary & 1.382 & .089 & 1.389 & .086 & 1.446 & .127 \\
\hline Age & 0.878 & .000 & .878 & .000 & .871 & .000 \\
\hline \multicolumn{7}{|l|}{ Hours worked per week (respondent) $\left(\right.$ Reference $=0$ hours, housework) ${ }^{d}$} \\
\hline Hours worked 1 to 20 hours & . & .327 & & .927 & & .665 \\
\hline Hours worked $=21$ to 30 & .856 & .318 & .962 & .886 & 1.169 & .644 \\
\hline Hours worked $=>30$ & .851 & .163 & 1.050 & .801 & 1.280 & .377 \\
\hline Number of children (Reference $=$ no children) & . & .000 & & .000 & & .000 \\
\hline 1 child & .330 & .000 & .341 & .000 & .341 & .000 \\
\hline 2 or more children & .029 & .000 & .030 & .000 & .027 & .000 \\
\hline Hours of household work by respondent & 1.006 & .020 & 1.006 & .028 & 1.000 & .004 \\
\hline $\begin{array}{l}\text { Share of household work by respondent }>75 \% \text { of household work } \\
\text { (Reference }=<75 \% \text { ) }\end{array}$ & .916 & .420 & 1.138 & .636 & 1.651 & .021 \\
\hline $\begin{array}{l}\text { Interaction of share of household work by number of children } \\
\text { (Reference }=<75 \% \text { of housework, no children) }\end{array}$ & & & & .969 & & .029 \\
\hline$>75 \%$ of household, 1 child & & & .948 & .834 & 0.656 & .016 \\
\hline$>75 \%$ of household, 2 or more children & & & .932 & .816 & 0.588 & .117 \\
\hline $\begin{array}{l}\text { Interaction of share of household work by hours worked } \\
\text { (Ref. }=<75 \% \text { of housework, } 0-20 \text { hours work) }\end{array}$ & & & & .406 & & .043 \\
\hline$>75 \%$ of household, 21 to 30 hours work & & & .868 & .664 & .822 & .644 \\
\hline$>75 \%$ of household, $>30$ hours work & & & .729 & .181 & .646 & .122 \\
\hline Constant & 200.712 & .000 & 171.549 & .000 & 143.233 & .000 \\
\hline \multirow[t]{2}{*}{$-2 \mathrm{LL}$} & 2927.351 & & 2925.533 & & 1591.933 & \\
\hline & & 3340 & & 3340 & & 1869 \\
\hline
\end{tabular}

Source: Netherlands, European Social Survey (ESS), Wave 2, 2004/5; Italy, Italian Multipurpose Survey - Family and Social Actors, 2003

Note: Reference group for intention to have another child is no.

${ }^{a}$ Model 1: base

${ }^{\mathrm{b}}$ Model 2: with interactions

${ }^{\mathrm{c}}$ Model 3: with interactions, only working women

${ }^{d}$ Reference category for model 3 is ( 1 to 20 hours) 
Mills et al.: Gender equity and fertility intensions in Italy and the Netherlands

\section{Results}

The first descriptive results within Table 1 provide clear evidence of similarities as well as differences between these countries. From these preliminary descriptive statistics, a first general conclusion is that the distribution of those who intend to have a child within the next three years is virtually the same in both countries. There is only a slightly higher intention expressed by Italian women (40.3) in comparison to their Dutch counterparts (35.6).

The most obvious difference is that Dutch women have higher education in comparison to their Italian counterparts, while 38 percent of Dutch women finished post-secondary or tertiary education, this accounts for only 10 percent of the Italian sample. A striking similarity in light of the educational differences is the fact that differences in the labour market participation of women in the Netherlands and Italy are relatively small. About 44 percent of women in both countries reports to be full-time housewives, Dutch women work more often part-time, 28 percent work 21-30 hours per week compared to 11 percent of Italian women. This high level of housewives in the Netherlands does not entirely reflect OECD and national estimates and therefore may be more of a selection effect in the collection of the ESS data.

A remarkable similarity is the share of household labour that women engage in within the household. Italy has a pronounced unequal division of household labour, with about 70 percent of women engaging in more than 75 percent of the household duties, while in the Dutch sample 60 percent of women report doing more than 75 percent of household duties. Conversely, around 40 percent of Dutch women do less than 75 percent of the housework, compared to 30 percent of Italian women.

Table 2 provides the estimate of the logistic regression analyses by country, starting with the base model and continuing with the full model that includes the interaction effects for all women (model 2) and working women only (model 3).

Our first hypothesis argued that women with higher education would have higher fertility intentions, due to their ability and power to bargain with a more even division of household labour, higher economic assets and ability to break traditional roles. This expectation is confirmed in both countries. We see that compared to those with lower education, both respondents and those with partners that have a higher education have higher fertility intentions. The effect is very similar across both countries and clearly significant in Italy. We also see that it is not only the highly educated, but those with a middle or upper secondary education, who also exhibit higher fertility intentions. The lack of high fertility intentions among those with lower education could be related to lack of resources, high expectations of investments in children or need to participate in the labour market, which is difficult to combine with parenthood in Italy. Having a child or fertility aspirations may be a 'luxury' in this context. 
Our second hypothesis predicted that women who engage in a large share of household labour ( $>75 \%$ ) would have lower fertility intentions. In the first model, we see no significant difference between the two groups of women, providing no clear evidence that an asymmetrical division of labour inhibits fertility intentions. However, role conflicts appear to dampen fertility intentions, as was predicted in our third hypothesis. Here we see that the result becomes significant when we enter the interaction effects. In this hypothesis we argued that it was not only a larger share of household labour (>75\%), but also working in a high number of hours in paid employment (>30 hours/week) and/or, already having one or more children that would lower fertility intentions. Both of these sub-hypotheses are supported, demonstrating the role conflict within the second shift. Compared to childless women who engage in less housework, mothers (with either one or two or more children) engaging in more than 75 percent of the housework have significantly lower fertility intentions. A similar finding also holds in relation to work hours. Compared to those with a lower share of housework and limited work hours (0-20/week), combining 75 percent of household tasks with higher work hours - particularly more than 30 hours a week - results in reduced fertility intentions for women. This is significant and particularly holds for Dutch women working more than 30 hours a week. Previous research (e.g., European Commission, 2005, p.42; Mills \& Täht, 2007) has demonstrated that it is structurally and normatively difficult for Dutch mothers to deviate from working part-time. The school system in the Netherlands, for instance, largely fosters a need for one parent to work part-time, constraining the full-time dual-earner model. This occurs in the form of structural and cultural norms, such as: generally two to three free afternoons per week for elementary school age children, the cultural norm that children return home each lunch hour, reticence to put children in daycare, and the structural lack of after-school care. Other control variables, such as age and number of children operate in the expected manner.

Our final hypothesis argued that women in Italy would face higher institutional and family constraints than in the Netherlands, which will in turn limit their fertility intentions. This hypothesis gains support when we compare the third model of working women only for the Netherlands and Italy. The effects are also generally more significant for the Italian case, particularly in relation to the share and hours of household work. 


\section{Discussion}

The goal of this paper was to provide an empirical test of gender equity theory by examining whether the unequal division of household labour leads to lower fertility intentions of women in the divergent institutional contexts of Italy and the Netherlands. A theoretical review demonstrated the need for a more gendered approach to the explanation of low fertility. An unequal division of labour within the household was positioned as a central link in understanding women's reduced fertility intentions. Contexts such as Italy are characterised by an extreme absence of institutions to reconcile work and parenthood for women such as a scarcity of public or subsidized childcare services and a 'male-breadwinner' model which reinforces a highly unequal division of household labour. The Netherlands shows slightly more institutional support via childcare availability and work-family reconciliation measures, such as the widely accepted norm of female part-time labour. Yet, these 'one-and-a-half-earner' households are still characterized by a highly unequal division of household labour, which may be related to engrained traditional values (de Graaff \& Vermeulen, 1997).

The empirical evidence does not provide clear support to directly link the asymmetrical division of household labour with lower fertility intentions. Rather, the story seems to rest on role conflicts. We did find that an asymmetrical division of household labour prompt women, and especially working women or mothers, to adjust their fertility intentions. This in turn means the reduction of, or even, forgone fertility. Those with higher education (and partners with higher education levels) showed higher fertility intentions, which we relate to a stronger bargaining power of women and the tendency of more highly educated couples to equally divide housework or possibly to outsource it.

In future studies, we would like to divide household labour from child and family care activities, which remained a problem. Another extension would be to examine not only fertility intentions, but also behaviour such as the transition to second child. Finally, fertility intentions were discussed and analyzed only in relation to women's and not couples' intentions. It is obvious that women do not make fertility decisions in a vacuum. An interesting future study would be to examine differences in the fertility intentions of men, women and joint couple decisions.

The comparative approach yielded a variety of interesting results. First and foremost there is a striking similarity in the division of household labour. In both countries, women do the majority of household labour, even when they engage in paid labour. The Dutch government was so concerned with this inequality that in 2006, they set a goal that men should carry at least 40 percent of the housework and caring duties (Portegijs et al., 2006). Since countless studies have shown that women's increased participation in paid labour does not result in a decrease in their own care and domestic 
duties (e.g., Drobnič, Blossfeld \& Rohwer, 1999), we question whether these types of goals are realistic. It may be more promising for women to 'outsource' household and childcare duties than to anticipate an equal distribution of household labour. Conversely, although not always a popular opinion in some circles, it also essential to consider the already large burden placed on the 'male-breadwinner,' particularly in these family-based societies. A reduction in men's paid workload and a more even distribution of paid labour between partners could also allow men to participate more fully in the household.

Another clear difference between these two countries was the higher employment of Dutch women and mothers, which is largely attributed to the opportunity for Dutch women to combine part-time work with parenthood. This type of employment appears to result in more possibilities to have children and, for the society, ultimately reach higher total fertility levels. This is in opposition to the 'either / or' possibility of parenthood versus employment in Italy, which operates largely as a deterrent for women to embark into parenthood or have further children. The underlying reasons for these differences are partially attributed to institutions, such as the lack of childcare in Italy, cultural acceptance of working mothers and availability of more flexible part-time jobs. It is also coupled with a persistent unequal division of household labour in both countries, which make it difficult for women, and couples, to break out of this position.

But is the introduction of more flexible employment measures, such as more possibilities for part-time work, a realistic solution for Italy? A gradual and non-radical solution such as this could be a more pragmatic strategy to counter low fertility in the Italian case. This fits with McDonald's (2000b: 433) assertion that "social norms may allow women's increased control over their own fertility within what is, in most respects, a male-dominated family system so long as their increased independence does not threaten the prevailing family system". In this sense, the Dutch model means that women are permitted and encouraged to marginally enter the labour market and remain virtually full-time mothers and housewives, which in turn does not threaten the malebreadwinner family model (Mills \& Täht, 2007).

Although the introduction of more flexible jobs with part-time labour for women could be a potentially beneficial solution to increase levels of fertility in Italy, it may not be effective in reducing long-term gender inequality. Previous studies have found that part-time work may enhance gender inequality and result in the further marginalization of women (e.g., Rubery, Horrell \& Burchell, 1994). Others (see Blossfeld \& Hakim, 1997) suggest that part-time work does not equalize women's position in comparison to full-time workers, but women in part-time jobs are not wholly marginalized either. In line with this study, these authors assert that part-time work, and employment in general, must always be examined while taking into account the household division of labour. Furthermore, we see that acceptance of part-time labour 
for women means that Dutch mothers often hold a 'triple burden' by engaging in the multiple roles of paid worker, primary household worker and primary carer for children. By taking a longer-term life course perspective, we also see that part-time work means the development of substantially different employment careers and incomes, that often progress at a significantly lower level than their male counterparts, even years after children have left the home (Hofmeister, Blossfeld \& Mills, 2006). In the event of divorce or widowhood, these women are at a higher risk of falling into poverty. Regardless of this problem, it is clear that gender equity both within and outside of the family is central factor in understanding low fertility.

\section{Acknowledgements}

We are grateful for the comments from the anonymous reviewers and those from Livia Olah, Rudi Wielers, Yi-Chun Ou, Kadri Täht, Irma Mooi-Reçi, Harry Ganzeboom, Femke Munniksma, Katya Ivanova, Marii Paskov and Dennis Raven. 


\section{References}

Alonso, F.G. (2004): The uneven distribution of family responsibilities between women and men, and its link with low fertility: some evidence for European Union countries from Eurobarometer data. Papers de demografia, $\mathrm{N}^{\circ}$. 253, Universidad de la Rioja, Spain.

Anxo. D., L. Flood, L. Mencarini, A. Pailhé, A. Solaz, and M.L. Tanturri (2007): Time Allocation between Work and Family Over the Life-Cycle: A Comparative Gender Analysis of Italy, France, Sweden and the United States. IZA Discussion Paper, No. 3193 (November), Available at SSRN: http://ssrn.com/abstract=1049381.

Becker, G.S. (1981). A Treatise on the Family. Cambridge, MA: Harvard University Press.

Becker, P.E. and P. Moen, (1999): Scaling Back: Dual-earner couples' work-family strategies, Journal of Marriage and the Family, 61(4): 995-1007.

Bernhardt, E.M. (1993): "Fertility and employment", European Sociological Review, 9 (1): $25-42$.

Bettio, F. and P. Villa (1998): A Mediterranean Perspective on the Break-down of the Relationship between Participation and Fertility, Cambridge Journal of Economics, 22 (2): 137-171.

Blossfeld, H.-P. and C. Hakim, (1997): Between Equalization and Marginalization: Women Working Part-time in Europe and the United States. New York: Oxford University Press.

Brewster, K.L. and R.R. Rindfuss (2000): "Fertility and women's employment in industrialized nations." Annual Review of Sociology, 26: 271-296.

Caldwell, J. and T. Schindlmayr, (2003): "Explanations of the fertility crisis in modern societies: A search for commonalities," Population Studies, 57(3): 241-263.

Chesnais, J.-C. 1996. "Fertility, family and social policy in contemporary Western Europe," Population and Development Review, 22(4): 729-739.

Cooke, L. P. (2003): The South revisited: The division of labor and family outcomes in Italy and Spain, IRISS Working Paper Series, no. 2003-12. CEPS/Instead, Luxembourg. 
CRRU (2004): Quality in early learning and child care services: Papers from the European Commission Childcare Network, Childcare Resource and Research Unit, Toronto, Canada.

Dalla Zuanna, G. (2001): “The banquet of Aeolus. A Familistic Interpretation of Italy's. Lowest-Low Fertility" Demographic Research, 4(5), 1-29.

Davis, K. 1937. "Reproductive institutions and the pressure for population," Sociological Review, 29 (July): 289-306, reprinted in (1997) Population and Development Review, 23 (3): 611-624.

De Graaf, P. and H. Vermeulen (1997): "Female Labour-Market Participation in the Netherlands: Developments in the Relationships between Family Cycles and Employment," pp. 191-209, In: Blossfeld, H.-P. and C. Hakim (Eds.) Between equalization and marginalization: Women working part-time in Europe and the United States of America, New York: Oxford University Press.

Del Boca, D. (2002): The effect of child care and part time opportunities on participation and fertility decisions in Italy, Journal of Population Economics, 15(3): 1432-1475.

Del Boca, D. and D. Vuri, (2007): The mismatch between employment and child care in Italy: the impact of rationing, Journal of Population Economics, 20 (4): 805832.

Drobnič, S., H.-P., Blossfeld, and G. Rohwer, (1999): Dynamics of women's employment patterns over the family life course: A comparison of the United States and Germany, Journal of Marriage and the Family, 61(1): 133-146.

Esping-Andersen, G. (1990): The Three Worlds of Welfare Capitalism. Cambridge: Polity Press.

European Commission (2005): Reconciliation of work and private life: A comparative review of thirty European countries, Luxembourg.

Folbre, N. (1983): Of patriarchy born: The political economy of fertility decisions, Feminist Studies, 9(2): 261-284.

Fuwa, M. (2004): "Macro-Level Gender Inequality and the Division of Household Labor in 22 Countries," American Sociological Review, 69(6): 751-767.

Gershuny, J. and Robinson, J.P. (1988): Historical Changes in the Household Division of Labor, Demography, 25(4): 537-552. 
Hochschild, A.R. with A. Machung. (1989): The second shift. Working parents and the revolution at home. Viking: New York.

Hofmeister, H., H.-P. Blossfeld and M. Mills (2006): "Globalization, uncertainty and women's mid-career life courses: a theoretical framework," pp. 3-31, In: H.-P. Blossfeld and H. Hofmeister (Eds.) Globalization, Uncertainty and Women's Careers: An International Comparison. Cheltenham, UK/Northampton, USA: Edward Elgar.

Kohler, H.P., F.C. Billari and J.A. Ortega, 2002. "The emergence of the lowest-low fertility in Europe during the 1990s," Population Development Review, 28 (4): 641-80.

Kravdal, O. (2007): "Effects of Current Education on Second- and Third-Brith Rates amoung Norwegian women and men born in 1964," Demographic Research, 17(9): 211-46.

Kreyenfeld, M. and Hank, K. (2000): "Does the availability of child care influence the employment of mothers? Findings from western Germany," Journal Population Research and Policy Review, 19(4): 317-337.

Lesthaeghe, R. (1995): "The Second Demographic Transition in Western Countries: An Interpretation,” pp. 17-62, In: K.O. Mason and A.-M. Jensen (Eds.) Gender and Family Change in Industrialized Countries. New York: Oxford University Press.

Lesthaeghe, R. and D.J. van de Kaa, (1986): Twee demografische transities? (Two Demographic Transitions?)., pp. 9-24, In: D.J. van de Kaa and R. Lesthaeghe (Eds), Bevolking: groei en krimp. Deventer: Van Loghum Slaterus.

Lo Conte, M. and S. Prati. (2003): "Maternità e partecipazione femminile al mercato del lavoro. Un'analisi della situazione professionale delle neo-madri" paper presented at Workshop Cnel-Istat on Motherhood and female participation to job market, between constraints and re-conciliation strategies, Rome (December 2)

Mason, K. and K. Oppenheim. (1997): Gender and Demographic Change: What do we know? In: G.W. Jones et al. (eds.), The Continuing Demographic Transition. Oxford: Clarendon Press, pp. 158-182.

Matthews, B.J. (1999): The Gender System and Fertility: An Exploration of the Hidden Links, Canadian Studies in Population, 26(1): 21-38.

McDonald, P. (2000a): "Gender equality, social institutions and the future of fertility," Journal of Population Research, 17(1): 1-16. 
Mills et al:: Gender equity and fertility intensions in Italy and the Netherlands

McDonald, P. (2000b): "Gender equity in theories of fertility transition," Population and Development Review, 26(3): 427-439.

McDonald, P. (2006): Low Fertility and the State: The Efficacy of Policy, Population and Development Review, 32(3): 485-510.

Mencarini, L. and M.L. Tanturri (2004): "Time use, family role-set and childbearing among Italian working women.”, Genus 60:111-137.

Mencarini, L. and M.L. Tanturri (2006): "High Fertility or Childlessness: Micro-Level Determinants of Reproductive Behaviour in Italy", Population, 61 (4): 389-416.

Miller Torr, B. M. and S. E. Short. (2004): "Second births and the second shift: A research note on gender equity and fertility." Population and Development Review 30 (1):109-130.

Mills, M. and H.-P. Blossfeld (2005): Globalization, Uncertainty and the Early Life Course: A Theoretical Framework, pp. 1-24, In: H.-P. Blossfeld, E. Klijzing, M. Mills and K. Kurz (Eds.) Globalization, Uncertainty and Youth in Society. London/New York: Routledge Advances in Sociology Series.

Mills, M. and K. Täht (2007): "The impact of non-standard work times on partnership quality and stability: Quantitative and qualitative findings from the Netherlands," Paper presented at the Population Association of America Meeting, New York, USA, March 29-31, 2007.

Mills, M., H.-P. Blossfeld and E. Klijzing (2005): "Becoming an Adult in Uncertain Times: A 14-Country Comparison of the Losers of Globalization," pp. 393-411, In: H.-P. Blossfeld, E. Klijzing, M. Mills and K. Kurz (Eds.) Globalization, Uncertainty and Youth in Society. London/New York: Routledge Advances in Sociology Series.

Morgan, S. P., Taylor, M.G. (2006): Low fertility at the turn of the Twenty-First Century, Annual Review of Sociology, 32: 375-99.

OECD (2006): OECD Factbook 2006: Economic, Environmental and Social Statistics. Geneva: OECD.

Olah L.Sz. (2003): Gendering fertility: Second births in Sweden and Hungary, Population Research and Policy Review, 22 (2), pp. 171-200.

Ongaro F. (2002): La bassa fecondità in Italia tra fattori esplicativi e implicazioni socio-economiche: conseguenze per la ricerca, paper presented at XLI Conference of the Italian Statitics Society (SIS), 5-7 June 2002. 
Oppenheimer, V.K. (1994): Women's rising employment and the future of the family in industrial societies" Population and Development Review, 20 (2): 293- 342.

Plantenga, J. (1996): For Women Only? The Rise of Part-time Work in the Netherlands, Social Politics, 3(1): 57-71.

Portegijs, W., B. Hermans, V. Laltha (2006): Emancipatiemonitor 2006: veranderingen in de leefsitutatie en levensloop. Den Haag: Sociaal en Cultureel Planbureau/Centraal Bureau voor de Statistiek.

Rindfuss, R.R., K.L. Brewster and A.L. Kavee (1996): "Women, work and children: Behavioural and attitudinal change in the United States," Population and Development Review, 22(3): 457-482.

Rubery, J., S. Horrell, and B. Burchell (1994). "Part-time Work and Gender Inequality in the Labour Market," In: A. MacEwen Scott (ed.) Gender Segregation and Social Change: Men and Women in Changing Labour Markets. New York: Oxford University Press.

Scisci A. and M. Vinci (2002): Differenze di genere, famiglia e lavoro, Carocci, Roma.

Tanturri M.L. and L. Mencarini (2008), "Childless or childfree? An insight into voluntary childlessness in Italy", Population Development Review, vol.34, n.1.

Tazi-Preve, I., D. Bichlbauer, A. Goujon (2004): Gender Trouble and Its Impact on Fertility Intentions, Yearbook of Population Research in Finland, n. 40, pp.5-24.

Teitelbaum, M.S. and J.M. Winter (1985): The Fear of Population Decline. Orlando, FL: Academic.

United Nations (2000): Replacement Migration: Is it a Solution to Declining and Aging Populations? ESA/P/WP.160. New York: United Nations.

van de Kaa, D.J. (1987): “Europe's Second Demographic Transition," Population Bulletin, 42(1): 1-59.

van de Kaa, D.J. (1996): "Anchored Narratives: The Story and Findings of Half a Century of Research into the Determinants of Fertility," Population Studies, 50(3): 389-432.

van der Lippe, T., and L. van Dijk, (2002): "Comparative Research on Women's Employment," Annual Review of Sociology 28, 221-241.

van Wel, F. and T. Knijn (2006): Transitional Phase or a New Balance? Working and Caring by Mothers With Young Children in the Netherlands, Journal of Family Issues, 27(5): 633-651. 
Mills et al:: Gender equity and fertility intensions in Italy and the Netherlands 